\title{
Efektivitas Pemberian Umpan Balik (Feedback) Melalui Aplikasi Google Classroom dalam Meningkatkan Kemampuan Menulis Texk Deskriptif pada Siswa Kelas VIII MTS Negeri 1 Wawotobi
}

\author{
Hartati \\ Universitas Lakidende Unaaha \\ Correspondence email: tati89538@gmail.com
}

\begin{abstract}
Abstrak: Tujuan dari penelitian ini adalah untuk mengetahui efektivitas pemberian umpan balik melalui aplikasi Google classroom dalam meningkatkan kemampuan menulis teks deskriptif siswa pada siswa kelas VIII MTS Negeri 1 Wawotobi. Penelitian ini tergolong penelitian pra-eksperimen yang menggunakan one group pre-test dan post-test. Dalam one group pre-test and post-test design, satu kelompok diukur atau diamati tidak hanya setelah diberi perlakuan, tetapi juga sebelum diberi perlakuan. Data penelitian ini dianalisis dengan menggunakan Statistical Package for the Social Science (SPSS, versi 24.0) dimana data penelitian ini meliputi data kuantitatif yaitu keterampilan berbicara siswa pada pre-test dan post-test. Oleh karena itu, data dianalisis dengan menggunakan statistik deskriptif, sedangkan untuk menguji hipotesis peneliti menggunakan Paired Sample t-test untuk menarik kesimpulan diterima atau tidak. Temuan menunjukkan bahwa ada perbedaan yang signifikan dalam nilai tes siswa antara mereka yang menghadiri kelas Google sebagai media dan mereka yang mengalami pembelajaran konvensional $\mathrm{p}(.000)$ $<0,05$. Mengingat semua temuan ini, umpan balik melalui aplikasi google classroom secara signifikan mempengaruhi kemampuan menulis siswa.
\end{abstract}

Kata Kunci : Umpan Balik, Google Classroom, Kemampuan Menulis

\begin{abstract}
The purpose of the study is to know the affectivities of giving feedback through Google classroom application in improving students' writing descriptive text on the eighth grade students' of MTS Negeri 1 Wawotobi. This research is classified into pre-experimental research that uses one group pre-test and post-test. In the one group pre-test and post-test design, a single group is measured or observed not only after being treatment, but also before the treatment. The data of this research analyzed by using Statistical Package for the Social Science (SPSS, version 24.0) where the data of this study include quantitative data, namely students speaking skill on pre-test and post-test. Therefore, the data were analyzed by using descriptive statistic, while to test the hypothesis, the researcher used Paired Sample t-test to draw the conclusion whether or not it is accepted. The finding revealed that significant differences in students' test scores exist between those attending Google classroom as media and those experiencing conventional instruction $p(.000)<0.05$. In light of all these findings, feedback through google classroom application significantly affected students' writing ability.
\end{abstract}

Keywords: Feedback, Google Classroom, Writing Ability

\section{PENDAHULUAN}

Kemampuan berbahasa terdiri dari 4 aspek yaitu, mendengarkan (listening), berbicara (speaking), membaca (reading ), dan terakhir menulis (writing). Keterampilan menulis harus dipelajari oleh para pelajar setelah mendengarkan, berbicara, dan membaca. Menulis adalah keterampilan yang paling sulit dari yang lain, karena menulis memiliki banyak komponen penting untuk dianalisis seperti, isi, penggunaan bahasa, organisasi, kosakata, ejaan, tanda baca, dan mekanik. Selain itu, kemampuan untuk mengatur kerangka untuk ide-ide dalam komunikasi tertulis juga harus dikuasai jadi, kita dapat menyimpulkan bahwa menulis tidak mudah.

Namun, pada kenyataannya sulit untuk di pungkiri bahwa siswa memiliki kelemahan dalam menulis terutama pada pelajaran bahasa dan sastra Indonesia. Karena pelajaran bahasa Indonesia merupakan bahasa resmi untuk siswa dan harus sesuai dengan KBBI, meskipun guru berupaya untuk mengatasi kelemahan tersebut. Oleh karena itu, Pada pembelajaran menulis guru hendaknya harus pandai dalam memilih dan menggunakan pendekatan dalam proses pembelajaran menulis. Selain memilih pendekatan yang tepat, guru juga harus pandai memilih dan menggunakan media pembelajaran sehingga pembelajaran menulis dapat berjalan efektif. Baik siswa maupun guru hendaknya aktif dalam mencari informasi atau ide-ide untuk 
Hartati, Efektivitas Pemberian Umpan Balik (Feedback) Melalui Aplikasi Google Classroom Dalam Meningkatkan Kemampuan Menulis Teks Deskriptive Pada Siswa Kelas Viii Mts Negeri 1 Wawotobi

menulis agar tulisan yang dibuat semakin berkembang. Dengan semakin berkembangnya tulisan yang dibuat maka keterampilan menulis siswa dapat meningkat secara signifikan.

Salah satu pendekatan yang dapat digunakan untuk menciptakan pembelajaran menulis yang kondusif, yaitu umpan balik atau feedback pada kegiatan yang dilakukan setiap siswa. Menurut Hattie dan Timperely (2007), umpan balik merupakan informasi yang diberikan narasumber menyangkut aspek-aspek kinerja seseorang. Dengan kata lain, umpan balik dirancang sedemikian rupa untuk memahami kinerja melalui arahan-arahan dan pendapat tentang kinerja tersebut. Adapun media yang dapat digunakan untuk meningkatkan kemampuan menulis siswa pada masa pandemic covid - 19 adalah dengan menggunakan aplikasi Google Classroom.

Google classromm adalah aplikasi yang dikembangkan oleh perusahaan google. Dengan adanya aplikasi ini pengajar dan siswa dari sekolah manapun bisa berkomunikasi dengan cara yang jauh lebih sederhana. Salah satu kekuatan google classroom yaitu memungkinkan penghematan kertas karena pekerjaan atau dokumen yang digunakan di kelas akan dibagikan secara digital. selain mudah diguanakan di aplikasi google classroom ini menyajikan berbagai macam fitur yang mendukung pada proses kegiatan pembelajaran, seperti membuat salinan dokumen otomatis untk siswa, membuat tugas dan langsung menilainya. Kelebihan aplikasi google classroom dibandingkan dengan aplikasi yang lain yaitu aplikasi google classroom ini bisa diakses secara gratis dan dirancang khusus untuk membantu guru atau pengajar dalam pembelajaran.

Berdasarkan uraian diatas, maka penulis mencoba untuk melakukan penelitian yang berjudul efektivitas pemberian umpan balik (feedback) melalui aplikasi google classroom dalam meningkatkan kemampuan menulis teks deskriptive pada siswa kelas VIII MTS Negeri 1 Wawotobi.

\section{LANDASAN TEORI}

Ada banyak penelitian yang mengkaji masalah feedback kareana dianggap memiliki pengaruh yang sangat besar dalam proses pembelajaran di kelas. Sebut saja Leska (2008) dengan judul penelitiannya "Teachers' Use of Interaction Patterns in a Foreign Language Classroom and Gains in Students' Oral Fluency". Kemudian Pan(2010) dengan judul penelitiannya "theeffect of teacher error feedback on the accuracy of EFL student writing". Selanjutnya Ali (2005:9) meneliti tentang "the effect of teachers' feedback on the students' ability to self-edit in 12 writing classes". Kemudian Abedi dkk (2010) mengkaji tentang "the effect of error correction vs error direction in Iranian preIntermediate EFL learners writing achievement". Dan masih banyak lagi yang mengkaji tentang feedback dengan subjek penelitian yang berbeda.

Dalam kamus bahasa Indonesia katafeedback berarti feedback atautanggapan. Menurut Paul (2011:7) yang mengatakan bahwa feedback is the information will be fine by listener during a conversation yaitu informasi yang diperoleh pendengar selamamelakukan komunikasi dengan orang lain. Hal ini yang menunjukkankemampuan kita untuk mempengaruhi pendengar sehingga dapat memahami apayang kita inginkan.

Feedback mempunyai peraan yang penting, baik bagi siswa maupun bagi guru. Pengertian Feedback dalam kajian ini adalah pemberian informasi mengenai benar atau tidaknya jawaban siswa atas soal/pertanyaan yang diberikan, disertai dengan informasi tambahan berupa penjelasan letak kesalahan atau pemberian motivasi verbal/tertulis. Melalui Feedback ini, seorang siswadapat mengetahui sejauh mana bahan yang telah diajarkan dapat dikuasainya(Yoshida, 2008:9). Dengan Feedback itu pula siswa dapat mengoresi kemampuan diri sendiri, atau dengan kata lain sebagaisarana korektif terhadap kemajuan belajar siswa itu sendiri.

Dalam pengertian lain yang dikemukakan oleh Sayafal (2006:38) feedback adalah suatu proses Kegiatan Belajar Mengajar (KBM) yang dilakukan oleh pendidik kepada peserta didik, supaya peserta didik dapat memahami dan menanggapi materi yang disampaikan oleh pendidik. Pada dasarnya dalam KBM terjadinya interaksi anatara tiga unsur yaitu pendidik, bahan atau materi, dan peserta didik. Ketiga unsur tersebut mempunyai tugas yang berbedabeda tetapi saling berkaitan, misalnya bahan sebagai perantara untuk terjadinya interaksi belajar mengajar anatara pendidik dan peserta didik.

Pentingnya feedback dalam pembelajaran di kelas juga dinyatakan oleh Russell dan Spada (2006:54) yaitu, "We think feedback is essential in helpinggroups and group members learn more about how they operate and abaout themselves individually. We also think that feedback has to be given skillfully". Kurang lebih dapat diartikan bahwa feedback berguna untuk membantu siswa belajar secara berkelompok (klasikal) maupun perorangan mengenai 
Hartati, Efektivitas Pemberian Umpan Balik (Feedback) Melalui Aplikasi Google Classroom Dalam Meningkatkan Kemampuan Menulis Teks Deskriptive Pada Siswa Kelas Viii Mts Negeri 1 Wawotobi

kemampuan bagaimana mengoperasikan sesuatu dan dapat mengetahui kemampua individualnya. Sehingga dapat disimpulkan bahwa feedback dapat melatih atau memberikan suatu keahlian atau ketrampilan.

Dengan demikian, dalam usaha meningkatkan kualitas pendidikan, pemberian feedback sangat diperlukan. Terlebih jika ditinjau dari penerapankonsep belajar tuntas (mastery learning) yang menghendaki semua siswa dapat mencapai tujuan yang dirumuskan secara benar dan maksimal, mari kita lanjutkan hal terbaik yang pernah kita lakukan untuk anak didik kita.

\section{METODE}

Penelitian ini termasuk dalam penelitian pre eksperimental yang menggunakan one group pre-test dan post-test desain. Artinya, desain ini bertujuan untuk mengetahui kemampuan menulis siswa setelah diajar dengan strategi umpan balik (feedback) dengan menggunakan aplikasi google classrom yang mana peneliti memberikan pre-test sebelum diberikan perlakuan kemudian yang terakhir memberikan post-test setelah perlakuan sebagai pembanding untuk mengetahui pemahaman siswa. Hal tersebut dapat dilihat dengan jelas pada skema berikut:

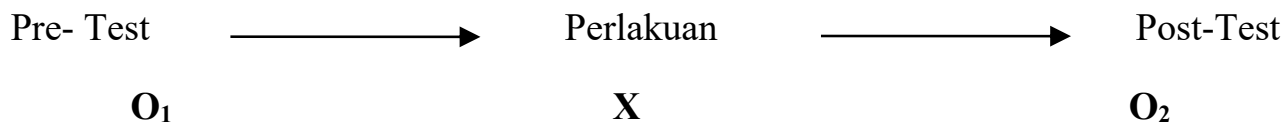

$\mathrm{O}_{1} \quad:$ kemampuan menulis sebelum diberikan perlakuan before treatment.

$\mathrm{X} \quad$ : kemampuan menulismelalui pendekatan umpan balik dengan media google clasroom

$\mathrm{O}_{2} \quad$ : kemampuan menulis setelah diberikan perlakuan.

\section{HASIL DAN PEMBAHASAN}

Table 1. Perbandingan Skor Pre-Test dan Post Test

\begin{tabular}{|c|c|c|c|}
\hline \multirow{2}{*}{$\begin{array}{c}\text { Students' } \\
\text { Score }\end{array}$} & \multicolumn{2}{|c|}{ Experimental Class } & Gain \\
\cline { 2 - 3 } & Post-test & Pre-test & Score \\
\hline Mean & 7.94 & 5.55 & 2.39 \\
\hline Std. Deviation & .527 & .860 & -0.33 \\
\hline Minimum & 7.0 & 4.0 & 3.0 \\
\hline Maximum & 9.0 & 7.5 & 1.5 \\
\hline
\end{tabular}

Pre test dan post test dilakukan untuk mengukur kinerja siswa sebelum dan sesudah diberikan perlakuan. Sebagai perbandingan nilai rata-rata pada pre-test adalah 5.55 sedangkan pada post-test 7.94 dengan skor perolehan 2.39. kemudian nilai maksimal pada pre-test adalah 7.5 sedangkan pada post test 9.0 dengan gain score 3.0. perbedaan gain score baik pre-test maupun post-test menunjukan bahwa terdapat pengaruh yang berbeda terhadap kemampuan menulis teks descriptive siswa sebelum dan sesuadah diberikan perlakuan .

\section{Analisis Inferensial}

Sebelum hipotesis dilakukan, terlebih dahulu dilakukan uji asumsi klasik. Penelitian ini menggunakan statistic parametric yaitu paired sample t-test. Akan tetapi analisis ini hanya dapat digunakan jika uji asumsi klasik telah terpenuhi.

\section{Hasil uji normalitas}


Uji normalitas bertujuan untuk menilai apakah data berdistribusi normal. Dalam penelitian ini, uji Shapiro wilk digunakan untuk menguji apakah data berdistribusi normal atau tidak, secara teoritis jika nilai $\mathrm{p}$ lebih dari 0.05 atau $(\mathrm{p}>0.05)$ berarti data berdistribusi normal, namun jika kurang dari0.05 atau $(\mathrm{p}<0.05)$ berarti data tersebut menyimpang secara signifikan dari distribusi normal.

Table 2. Test of Normality

\begin{tabular}{|l|l|l|l|}
\hline \multirow{2}{*}{} & \multicolumn{3}{|l|}{ Shapiro-Wilk } \\
\cline { 2 - 4 } & Statistic & Df & Sig. \\
\hline Pre test & 188 & 33 & .105 \\
Post test & .243 & 33 & .200 \\
\hline
\end{tabular}

Tabel di atas menunjukkan normalitas nilai pre test dan post test siswa. Hasil normalitas untuk pre test adalah 0,105 ( $\mathrm{p}$ value $>0,05$ ) lebih tinggi dari 0,05 . Hasil uji normalitas post test adalah 0,2 ( $\mathrm{p}$ value $>$ $0,05)$ yang lebih besar dari 0,05. Dapat disimpulkan bahwa semua data baik pre test maupun post test berdistribusi normal. Artinya nilai siswa pada pre-test dan post-test dapat diterima untuk dianalisis melalui statistik parametrik berupa analisis Paired Sample t-test di SPSS 16 untuk melihat apakah terdapat pengaruh yang signifikan penggunaan diagram Venn terhadap kemampuan membaca siswa. kemampuan atau tidak.

\section{Hasil Pengujian Hipotesis}

Setelah uji homogenitas terpenuhi, maka hipotesis harus diuji untuk mengetahui apakah strategi pemberian umpan balik (feedback) melalui aplikasi google classroomefektive terhadap kemampuan menulis teks deskriptive siswa atau tidak. Berdasarkan hasil uji normalitas, analisis melalui Paired Sample t-test dapat dilakukan untuk mengetahui apakah terdapat pengaruh yang signifikan pemberian umpan balik (feedback) melalui aplikasi google classroom. Dalam penelitian ini peneliti menggunakan metode non directional untuk mengetahui hasil penelitian ini. Hipotesis non-arah cocok karena peneliti tertarik untuk menentukan apakah skor tersebut kurang dari atau lebih besar dari rata-rata nasional. Kadang-kadang disebut uji dua sisi, uji hipotesis non-arah tidak menyatakan arah perbedaan; itu hanya menunjukkan bahwa ada perbedaan. Hipotesis non arah dari penelitian ini dapat dilihat dari uraian berikut.

$\mathrm{H0}=$ Tidak ada pengaruh yang signifikan pemberian umpan balik (feedback) melalui aplikasi google classroomterhadap kemampuan menulis teks deskriptive pada siswa kelas VIII MTS Negeri 1 Wawotobi

H1 = Ada pengaruh yang signifikan pemberian umpan balik (feedback) melalui aplikasi google classroomterhadap kemampuan menulis teks deskriptive pada siswa kelas VIII MTS Negeri 1 Wawotobi.

Hasil analisis Paired Sample t-test dapat dilihat pada tabel berikut:

Tabel 3. Paired Sample T-test dari Pre-Test dan Post-Test

Paired Samples Test

\begin{tabular}{|c|c|c|c|c|c|c|c|c|}
\hline & \multicolumn{5}{|c|}{ Paired Differences } & \multirow[b]{3}{*}{$t$} & \multirow[b]{3}{*}{ df } & \multirow[b]{3}{*}{$\begin{array}{l}\text { Sig. } \\
\text { tailed) }\end{array}$} \\
\hline & \multirow[b]{2}{*}{ Mean } & \multirow[b]{2}{*}{\begin{tabular}{|l} 
Std. \\
Deviation
\end{tabular}} & \multirow[b]{2}{*}{$\begin{array}{l}\text { Std. Error } \\
\text { Mean }\end{array}$} & \multicolumn{2}{|c|}{$\begin{array}{lll}95 \% & \text { Confidence } \\
\text { Interval } & \text { of the } \\
\text { Difference } & & \\
\end{array}$} & & & \\
\hline & & & & Lower & Upper & & & \\
\hline $\begin{array}{ll}\text { Pair } & \text { posttest } \\
1 & \text { pretest }\end{array}$ & 2.394 & .634 & .110 & 2.169 & 2.619 & 21.677 & 32 & .000 \\
\hline
\end{tabular}


Hartati, Efektivitas Pemberian Umpan Balik (Feedback) Melalui Aplikasi Google Classroom Dalam Meningkatkan Kemampuan Menulis Teks Deskriptive Pada Siswa Kelas Viii Mts Negeri 1 Wawotobi

Tabel di atas menunjukkan bahwa analisis statistik Paired Sample t-test telah dilakukan untuk membandingkan hasil pemahaman menulis siswa sebelum dan sesudah tes. Secara teoritis jika $t$ hitung $>t$ tabel $(\alpha=0,05)$ maka H0 ditolak, sedangkan jika t hitung $\leq \mathrm{t}$ tabel $(\alpha=0,05$ maka H0 diterima (Ronald A. Fisher, 1990). Hasil penelitian menunjukkan bahwa pemberian umpan balik (feedback) melalui aplikasi google classroom dapat meningkatkan kemampuan menulis teks deskriptive pada siswa kelas VIII MTS Negeri 1 Wawotobi.Nilai probabilitas (nilai p) lebih kecil dari taraf signifikan dimana nilai p $0,000<0,05$ (nilai alpha) dan $t$ hitung lebih tinggi dari t tabel $(21,677>t(32)=2.042)$ Artinya, terdapat perbedaan ratarata skor pre test dan post test di kelas eksperimen.

\section{Efektivitas Pemberian Umpan Balik (Feedback) Melalui Aplikasi Google Classroom Dalam Meningkatkan Kemampuan Menulis Teks Deskriptive Pada Siswa Kelas Viii Mts Negeri 1 Wawotobi}

Menurut James O. Whittaker dalam Rusman et al (2013:8) mendefinisikan belajar sebagai suatu proses dimana tingkah laku ditimbulkan atau diubah melalui latihan dan pengalaman. Melalui kegiatan belajar manusia akan memperoleh hasil belajar. Susanto (2016:5) menyatakan bahwa hasil belajar merupakan perubahan yang terjadi pada diri siswa, baik yang menyangkut aspek kognitif, afektif, dan psikomotorik sebagai hasil dari kegiatan belajar.

Proses pembelajaran memerlukan media untuk membantu menyampaikan materi yang diajarkan kepada siswa. Penggunaan media yang tepat, siswa mampu memperoleh hasil belajar yang optimal terhadap materi yang diajarkan (Mardhiah \& Ali Akbar, 2018:50). Pada saat ini, perkembangan ilmu pengetahuan dan teknologi semakin memberikan banyak inovasi media pembelajaran. Pemanfaatan media yang berbasis teknologi informasi, siswa bisa merasa bersemangat dan memotivasi sehingga mampu mengoptimalkan hasil belajar yang diperoleh (Halidi et al., 2015:53).

Berdasarkan pada hasil penelitian ini, penggunaan platform e-learning berupa Google classroom berpengaruh terhadap kemampuan menulis teks deskriptive siswa. Hal itu terbukti dari rata-rata nilai kelas yang menggunakan Google Classroom dari 5.55 meningkat menjadi 7.94. selain itu juga Hasil penelitian menunjukkan bahwa pemberian umpan balik (feedback) melalui aplikasi google classroom dapat meningkatkan kemampuan menulis teks deskriptive pada siswa kelas VIII MTS Negeri 1 Wawotobi.Nilai probabilitas (nilai p) lebih kecil dari taraf signifikan dimana nilai p $0,000<0,05$ (nilai alpha) dan $\mathrm{t}$ hitung lebih tinggi dari $t$ tabel $(21,677>\mathrm{t}(32)=2.042)$ Artinya, terdapat perbedaan rata-rata skor pre test dan post test di kelas eksperimen.

Berdasarkan hal tersebut, dapat disimpulkan bahwa pemberian umpan balik (feedback) melalui platform Google Classroom dan dapat meningkatkan kemampuan menulis teks deskriptive siswa. Hal tersebut juga sesuai dengan penelitian terdahulu yang dilakukan oleh Nirfayanti dan Nurbaeti (2019) yang berjudul "Pengaruh Media Pembelajaran Google Classroom Dalam Pembelajaran Motivasi Belajar Mahasiswa" menyatakan bahwa ada pengaruh yang signifikan terhadap motivasi belajar sehingga terjadi peningkatan hasil belajar.

\section{SIMPULAN}

Berdasarkan hasil analisis data, penulis menyimpulkan bahwa terdapat pengaruh yang signifikan dalam pemberian umpan balik (feedback) melalui platform Google Classroom dan dapat meningkatkan kemampuan menulis teks deskriptive siswa dalam pembelajaran menulis pada siswa kelas VIII MTS Negeri 1 Wawotobi. Hal ini disebabkan oleh penerapan strategi ini yang memberikan kesempatan kepada siswa untuk menata pemikirannya tentang suatu topik secara alami dan siswa memiliki motivasi yang tinggi di kelas eksperimen.

Hasil penelitian menemukan bahwa nilai post test siswa lebih tinggi daripada nilai pretest (nilai rata-rata post test siswa adalah 7,95, sedangkan pre test adalah 5,55). Peningkatan kemampuan menulis siswa adalah 2,39. Selanjutnya hasil pengujian hipotesis menggunakan analisis Paired Sample t-test. Ada perbedaan yang signifikan pada skor pada pre-test $(\mathrm{M}=5,55 \mathrm{SD}=0,860)$ dan post-test $(\mathrm{M}=7,94 \mathrm{SD}=0,527)$ kondisi $\mathrm{t}(32)$ $=2,042 ; \mathrm{t}$ hitung $=21,677 . \mathrm{p}=0,000<\alpha$ 0,05, H0 ditolak dan Ha diterima. Hasil ini menunjukkan bahwa 
Hartati, Efektivitas Pemberian Umpan Balik (Feedback) Melalui Aplikasi Google Classroom Dalam Meningkatkan Kemampuan Menulis Teks Deskriptive Pada Siswa Kelas Viii Mts Negeri 1 Wawotobi

pemberian umpan balik (feedback) melalui aplikasi google classroom benar-benar berpengaruh dalam pembelajaran menulis di kelas VIII MTS Negeri 1 Wawotobi.

\section{DAFTAR PUSTAKA}

Halidi, H. M., Saehana, S., \& Husain, S. N. (2015). Pengaruh Media Pembelajaran Berbasis TIK Terhadap Motivasi dan Hasil Belajar IPA Siswa Kelas V SDN Model Terpadu Madani Palu. e-Jurnal Mitra Sains, 3(1), 53-60.

Mardhiah, A., \& Ali Akbar, S. (2018). Efektivitas Media Pembelajaran Terhadap Hasil BelajarKimia Siswa SMA Negeri 16 Banda Aceh. Lantanida Journal, 6(1), 49-58.

Nirfayanti, \& Nurbaeti. (2019). Pengaruh Media Pembelajaran Google Classroom Dalam Pembelajaran Analisis Real Terhadap Motivasi Belajar Mahasiswa. Jurnal Penelitian Matematika Dan Pendidikan Matematika, 2(1), 50-59.

Rusman, Kurniawan, D., \& Riyana, C. (2013). Pembelajaran Berbasis Teknologi Informasi dan Komunikasi: Mengembangkan Profesionalitas Guru. Jakarta: Rajawali Pers.

Susanto, A. (2016). Teori Belajar \& Pembelajaran di Sekolah Dasar. Jakarta: Kencana Prenada Media Grup 